\title{
Deepening Cooperation
} Between Saudi Arabia

and China

Dongmei Chen, Wenke Han 


\section{About KAPSARC}

The King Abdullah Petroleum Studies and Research Center (KAPSARC) is a non-profit global institution dedicated to independent research into energy economics, policy, technology and the environment, across all types of energy. KAPSARC's mandate is to advance the understanding of energy challenges and opportunities facing the world today and tomorrow, through unbiased, independent, and high-caliber research for the benefit of society. KAPSARC is located in Riyadh, Saudi Arabia.

\section{Legal Notice}

(C) Copyright 2019 King Abdullah Petroleum Studies and Research Center (KAPSARC). No portion of this document may be reproduced or utilized without the proper attribution to KAPSARC. 


\section{Key Points}

he comprehensive strategic partnership between China and the Kingdom of Saudi Arabia has presented opportunities for a new level of collaboration at a time when both countries are seeking economic transformation and sustainable growth.

A structured policy coordination framework has facilitated cooperation in building local industries and constructing new cities in Saudi Arabia.

Despite the progress made to date, significant gains can still be achieved by lowering trade barriers and improving the bilateral coordination of national regulations, planning, and investment.

Total investment flows between China and Saudi Arabia increased more than twentyfold from 20052015. Opening up the domestic market in both countries and increasing Belt and Road Initiative (BRI) related investment may help in dealing with challenges in the global investment environment and improve the alignment of domestic development goals.

Establishing new financial instruments that build on the existing networks and a potential arrangement of Chinese yuan settlement can increase investment flows.

From 2011-2016, there was a 50\% increase in Chinese citizens working in the Kingdom and over 1,000 Saudi students were studying in China each year. This exchange of human capital has benefited the economies of both countries.

Three strategic areas are identified for deeper cooperation:

Extending energy cooperation from traditional oil and gas to new low carbon technologies.

Integrating petrochemical industry development across the value chain.

Building local strength in industrial capacity by capturing the market potential of new construction.

This paper identifies five steps that could enhance the existing model of collaboration: defining a bridging strategy, building capacity, establishing a free trade agreement, encouraging a new partnership for financing, and building a joint research platform for energy collaboration. 
$\mathrm{n}$ recent decades China and Saudi Arabia have gradually deepened their collaboration in many areas. Five indicators are used to assess the overall progress of the two countries' collaboration and to help form recommendations for ways to improve the integration between China's Belt and Road Initiative (BRI) and Saudi Vision 2030.

\section{Policy coordination}

The Saudi-Chinese High-Level Joint Committee has structured the official channels for policy coordination. Significant progress has been achieved under this framework to facilitate cooperation between the BRI and Vision 2030.

This includes the establishment of a joint investment fund, the construction of the Chinese Industrial Park in Jazan city, and the finalization of an energy cooperation package.

\section{Trade interdependence}

Trade between China and Saudi Arabia has grown rapidly, increasing from \$4 billion in 2001 to $\$ 73$ billion in 2012. Imports of Saudi products have constituted an important part of China's manufacturing for global markets, while Saudi Arabia's imports from China have helped satisfy Saudi Arabia's growing need for economic and social development. Lowering trade barriers offers significant scope for mutual benefit.

\section{Investment interdependence}

Investment flows between China and Saudi Arabia increased more than twentyfold from 2005-2015. Given rising global trade and investment tensions, growing regional conflicts and the increasing challenges of aligning domestic development priorities, opening up domestic markets in both countries and diverting more investment from China to Saudi Arabia through BRI collaboration may create new opportunities for growth.

\section{Financial integration}

China and Saudi Arabia have successfully collaborated in many finance-related areas, including improved compliance with international regulations, an extended network of banking services, and joint efforts to establish new investment funds and investment institutions. Chinese yuan settlement could encourage investment flows to help fund infrastructure construction and diversified industrial development.

\section{People-to-people exchange}

Cultural exchanges and better connections between people have improved the economic ties between China and Saudi Arabia. From 2011-2016, there was a $50 \%$ increase in Chinese citizens working in the Kingdom and over 1,000 Saudi students studied in China every year. This exchange of human capital has benefited the economies of both countries. In the future, tourist flows from China to Saudi Arabia could provide a further boost to the Saudi economy.

Future collaboration between China and Saudi Arabia, focused on the three areas below, could help maximize the benefits from economic transformation while reducing the risks of structural change and trade conflicts.

Energy at the core of cooperation. Energy trade and investment have historically been essential components of the cooperation between China and Saudi Arabia. The evolutions of economic strategy in both countries have led to a change in energy cooperation. The scope is extended from emphasizing traditional fossil energy cooperation to prioritizing green low carbon energy. The process is changing from national to joint planning and the joint promotion of cooperative projects.

\section{Integrating petrochemical industry} development across the value chain. The recreation of the petrochemical industry in the 
global supply chain creates new opportunities for both countries. The partnerships between businesses and joint initiatives between businesses and governments are optimizing the value of production and market expansion.

\section{Building industrial strength by realizing the} potential of construction. To double the Kingdom's GDP by 2030 , half of the $\$ 4$ trillion investment needed will be spent on infrastructure. The integration of industrial development with construction projects could increase the financial liquidity of infrastructure on the one hand and improve the productivity of local industries on the other.

Five steps are identified that could help develop a new level of collaboration between China and Saudi
Arabia and translate both countries' complementary advantages into mutual benefits. They are:

Defining a bridging strategy at the implementation level.

Building a capacity system for BRI engagement.

Facilitating free trade agreement negotiations.

Encouraging new partnerships and creating a framework for infrastructure financing.

Building a joint research platform for energy collaboration. 


\section{Indicators for Assessing Bilateral Cooperation}

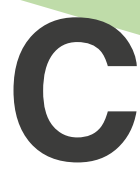

hina proposed the Belt and Road Initiative (BRI) in 2013 with the aim of promoting a more integrated regional market and more efficient use of economic resources through broader and deeper cooperation with the countries involved. The BRI has the potential to shape the landscape of international cooperation substantially. If BRI countries can satisfy their need for infrastructure improvement and industry modernization, the BRI will stimulate new growth for the world economy and contribute over $80 \%$ to global economic growth by 2050 (Barton et al. 2015). Some analysts have overstated the geostrategic dimensions of the BRI while underplaying its economic agenda (Johnson 2016; Small 2015). This paper supports the idea that economic cooperation is the primary objective of the BRI, with improved infrastructure and economic ties helping to strengthen China's political position in the region.

To date, more than 100 countries and international organizations have signed BRI cooperation agreements with China. The trade volume between China and the BRI countries exceeds \$4 trillion and total investment exceeds $\$ 60$ billion. More than 75 economic and trade zones and 200,000 jobs have been created in partner countries (Ma 2018). The implementation of the BRI could help spur new developmental initiatives in recipient countries (Hobbs 2018). It may also act as an enabler of key gains for partner countries, including strengthened backward and forward linkages within BRI partner countries, greater access to supply chains, enhanced network effects, alleviated financing constraints, and inflows of technical and management know-how (Balazs 2016).

The ambition of Saudi Vision 2030 is for Saudi Arabia to be at the heart of the Arab and Islamic worlds, to become a global investment powerhouse, and to be a global hub connecting Asia, Europe, and Africa. To achieve this, the Kingdom needs to diversify its economy away from its reliance on petroleum toward a more balanced, sustainable development model. Saudi Arabia is driving a series of initiatives and forums to encourage investment in new infrastructure and industrial cities, increasing the strength of its industrial production, and extending the downstream value of its petrochemical industry.

Combining the BRI with Vision 2030 could help achieve development goals for both countries. This research seeks to gauge the collaboration between China and Saudi Arabia and to suggest ways in which the relationship between these countries can be improved and enhanced for their mutual benefit.

This study employs indicators that help assess the degree of economic integration and cooperation among different economies. Previous studies have used regional price convergence to track market integration, apply intraregional income gaps to assess economic convergence or track common structural changes as hallmarks of economic integration (Dreher 2006; Chen and Woo 2008). In their working paper for the Asian Development Bank, Capannelli et al. (2009) analyzed the evolution of Asian regional economic integration in areas such as production and investment, finance, macroeconomic links, and people-to-people exchanges. Mukherji and lyengar (2013) suggested scope for deepening economic cooperation between Sri Lanka and India by analyzing the foreign direct investment (FDI) flow, the integration of intra-industry trade, the comparative advantages in services, and the performance of policy agreements. Chen and Yang (2017) assessed the relationship between China and 16 Central and Eastern European countries through the lens of 
political cooperation, trade cooperation, finance cooperation, investment cooperation and people-topeople exchange. The Boao Forum for Asia (BFA) (2018) illustrated the challenges of Asian economic integration through evaluating the interdependence among major Asian economies in trade, FDI, 'Factory Asia,' and service and financial integration.
Drawing on approaches from these studies, this paper focuses on the assessment of five key indicators: policy coordination, trade flow, FDI flow, financial integration, and people-to-people exchanges. These are important components for both the BRI and Vision 2030. Table 1 details the indicators used in this study.

Table 1. Key indicators used to assess the integration of the BRI and Saudi Vision 2030.

\begin{tabular}{|c|c|c|}
\hline & Key indicators & BRI and Vision 2030 \\
\hline 1 & Policy cooperation & $\begin{array}{l}\text { - State visits and joint statements. } \\
\text { - Formal agreements designed to lead the cooperation process. } \\
\text { - High-level regional or intergovernmental forums. } \\
\text { - Mechanisms to improve cooperation in practice. } \\
\text { - Informal measures to manage the consequences of cooperation. }\end{array}$ \\
\hline 2 & Trade integration & $\begin{array}{l}\text { - Interdependence of trade flows. } \\
\text { - Interdependence of exports. } \\
\text { - Trade volumes. } \\
\text { - Import and export structures. } \\
\text { - Trade agreements. }\end{array}$ \\
\hline 3 & FDI integration & $\begin{array}{l}\text { - Interdependence of two-way FDI flows. } \\
\text { - Interdependence of inward FDI flows. } \\
\text { - Evolution of inward FDI flows. }\end{array}$ \\
\hline 4 & Financial integration & $\begin{array}{l}\text { - Arrangements to facilitate information exchange and financing cooperation. } \\
\text { - Infrastructure financing. } \\
\text { - Currency collaboration. }\end{array}$ \\
\hline 5 & People-to-people exchange & $\begin{array}{l}\text { - Labor migration. } \\
\text { - Education and training exchange. } \\
\text { - Culture and tourism development. }\end{array}$ \\
\hline
\end{tabular}

Source: KAPSARC, based on Chen and Yang (2017) and BFA (2018). 


\section{Status of Collaboration in Five Domains}

\section{Policy cooperation}

Relations between China and Saudi Arabia have been positive at both the diplomatic and political levels since 1990. The two countries established strategic and friendly relations in June 2008 , signing a comprehensive strategic partnership in January 2016. Frequent high-level exchanges have taken place in that time, including state visits of King Salman and the Crown Prince of Saudi Arabia to China and state visits of Chinese presidents and premiers to Saudi Arabia. Beijing and Riyadh have reached a broad consensus on bilateral cooperation in fields such as energy, trade, investment, industrial capacity and infrastructure construction. Table 2 summarizes the key bilateral agreements between China and Saudi Arabia.

The establishment of the Saudi-Chinese HighLevel Joint Committee in 2016 signaled an important step in this new partnership. The committee acts as the mechanism for planning and coordinating policy cooperation between the BRI and Vision 2030. Chinese Vice Premier Zhang Gaoli and Saudi Crown Prince Mohammad bin Salman co-chaired the first meeting of the High-Level Joint Committee in Beijing in August 2016. Six sub-committees were established for political and diplomatic affairs: the BRI, major cooperation projects, energy, trade and investment, culture, technology and tourism. The Chinese National Development and Reform Commission (NDRC) and the Saudi Ministry of Energy, Industry and Mineral Resources (MEIM) co-chaired the sub-committees on the BRI, key project investment and energy cooperation. China's Ministry of Commerce (MOFCOM) and Saudi Arabia's Ministry of Commerce and Investment (MCl) co-chaired the sub-committee for trade and investment.

Table 2. Summary of bilateral agreements between China and Saudi Arabia.

\begin{tabular}{l|l} 
Agreement on economic, trade, investment and technology cooperation & November 5,1992 \\
\hline Agreement to encourage and protect each other's investment & February 29,1996 \\
\hline Agreement on developing oil, gas and mineral resources cooperatively & January 23,2006 \\
\hline Agreement to avoid double taxation and prevent tax evasion for income and property & January 23, 2006 \\
\hline Agreement on civil aviation & July 23, 2007 \\
\hline Joint statement on strengthening cooperative and strategically friendly relations & June 21,2008 \\
\hline Agreement to strengthen cooperation on infrastructure construction & June 21,2008 \\
\hline $\begin{array}{l}\text { Supplementary memorandum of understanding (MOU) on developing oil, gas and mineral } \\
\text { resources cooperatively }\end{array}$ & February 10,2009 \\
\hline MOU to promote the Belt and Road Initiative and industrial capacity cooperation & January 19,2016 \\
\hline Joint statement on establishing comprehensive and strategic partnerships & January 19,2016
\end{tabular}

Source: KAPSARC, based on Chinese government documents. 
During the second meeting of the High-Level Joint Committee in Riyadh in August 2017, Vice Premier Zhang Gaoli and Crown Prince Mohammad bin Salman advanced the cooperation between both countries in several key areas (Asharq Al-Awsat 2017):

MEIM and NDRC signed an MOU to establish a $\$ 20$ billion joint investment fund and provide financing support for infrastructure construction, energy and mineral resources development in Saudi Arabia.

$\mathrm{MCl}$ and MOFCOM agreed on a five-year plan for joint action, which acts as the mechanism to enhance commercial cooperation between the two countries.

Agreements to build an energy cooperation package and advance the construction of the Chinese Industry Park in Jazan, Saudi Arabia.

Policy coordination between China and Saudi Arabia has also been strengthened through multilateral cooperation frameworks such as the China-Arab States Cooperation Forum and the China-Gulf Cooperation Council (GCC) Strategic Dialogue. At the sixth ministerial meeting of the China-Arab States Cooperation Forum in June 2014, President $X i$ Jinping proposed a ' $1+2+3$ ' cooperation model between China and the Arab States, comprising i) energy, ii) infrastructure construction and trade and investment, and iii) nuclear energy, space satellite and new energy. In May 2016, the seventh ministerial meeting of the forum further specified collaboration in three key areas: infrastructure connectivity, industrial capacity cooperation and people-to-people exchanges. The initiatives arising from the forum add to Saudi Arabia's economic diversification drives.
Increased exchange of information between Chinese and Saudi businesses will help the implementation of the BRI and Vision 2030. MOFCOM's "Guidance of Outward Investment in Saudi Arabia 2017," released on its public service platform, was intended to help Chinese businesses understand the political and cultural circumstances of Saudi Arabia and to present the strategic opportunities offered by the Kingdom's economic transition. The Economic and Commercial Counsellor's Office of the Chinese Embassy in Saudi Arabia detailed the opportunities for Chinese businesses in nine sectors outlined in Vision 2030 in a series of analyses. On its website, the Saudi Arabian General Investment Authority presented opportunities for investment in chemicals, information and technology, energy and water, industrials and manufacturing, healthcare and life sciences, and emerging sectors. To seek partners to jointly develop and operate the industrial cities, the Saudi government shared its plans, including policies, widely. All this information provides valuable references for businesses trying to decide whether and where to invest in Saudi Arabia.

However, business decision-making is also influenced by social relationships, cultural values, moral concerns, political and religious views. This is known as 'embeddedness,' a term that describes the constraints of non-economic factors on economic activity. Even when government plans indicate significant opportunities in the medium to long term, Chinese businesses have not shown a preference to invest in Saudi Arabia over, for example, countries in Southeast Asia. One major reason is that it requires much more effort to build local connections in the Kingdom and embed a business socio-culturally, compared with the level of effort required to do the same in Southeast Asian countries (Liu 2017). The issue of 'embeddedness' needs to be addressed by both countries in their policy coordination. 


\section{Trade interdependence}

The trade interdependence between China and Saudi Arabia can be measured as the share of intra-country trade over total trade with the world, defined as:

Inter $_{\text {trade }}=\left(E X_{i j}+I M_{i j}\right) /\left(E X_{i}+I M_{i}\right)$

Where,

$E X_{i j}=$ exports of country $i$ to country $j$;

$I M_{i j}=$ imports of country $i$ from country $j$;

$E X_{i}=$ total exports of country $i$;

$I M_{i}=$ total imports of country $i$.

The change in the share of trade reflects the relative importance of specific intra-country trade versus external trade dependence. It lies between zero and one, with a higher value representing a higher degree of trade interdependence. Figure 1 shows the trade dependence of the Kingdom on China increased to $14.4 \%$ in 2017 , from $4.2 \%$ in 2001 . In contrast, China's trade dependence on the Kingdom

Figure 1. Trade interdependence between China and Saudi Arabia.

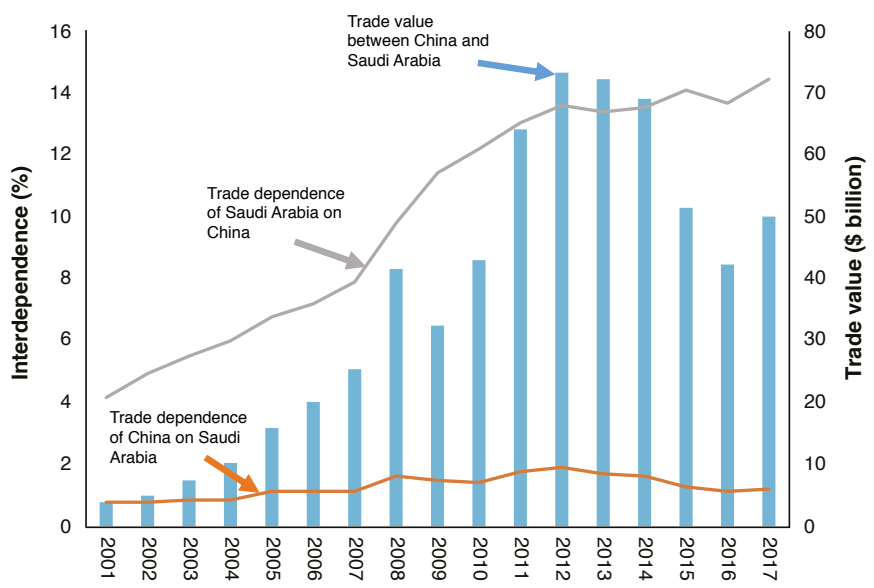

Source: KAPSARC, based on ITC (2018). remained at a relatively low level and only changed slightly between 2001 and 2017. China's relative lack of dependence on trade with Saudi Arabia is due to its trade diversification across the world - China's trade with Saudi Arabia only represents a small fraction of its global trade.

The deepened partnership between China and Saudi Arabia has significantly improved the trade flow between the two countries. China has become Saudi Arabia's largest global trading partner, and Saudi Arabia is now China's largest trading partner in the Middle East and North Africa (MENA) region. The value of trade between the two countries grew from $\$ 4$ billion in 2001 to $\$ 73$ billion in 2012. Saudi Arabia's exports to China rose twentyfold during the same period, from \$2.7 billion in 2001 to $\$ 54$ billion in 2012 (Figure 2). The high oil price was a major driver in pushing up the value of Saudi Arabia's exports to China, which was around three times the value of exports from China to Saudi Arabia during 2008-2014. Despite the oil price dropping sharply in 2015 and 2016, the Kingdom's exports of oil to China remained stable at around 50 million tonnes per year.

Figure 2. Exports between China and Saudi Arabia.

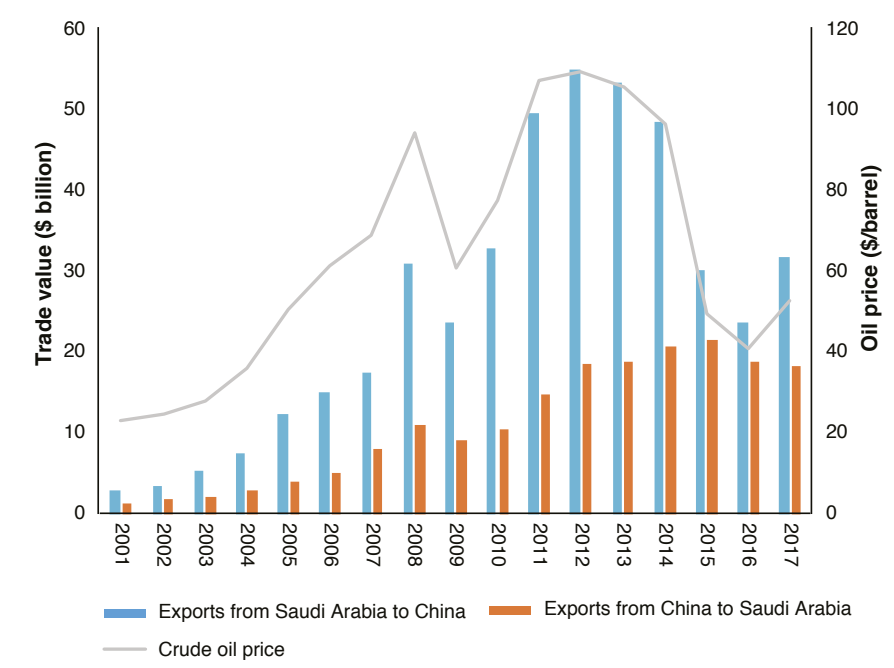

Source: KAPSARC, based on ITC (2018). 
Both countries have benefitted from a complementary trade structure. China has advantages in manufactured products, while Saudi Arabia is very competitive in energy products (CDB et al. 2017). As shown in Figure 3 and Figure 4, exports from Saudi Arabia to China are dominated by petroleum and petrochemical products (99\% mineral fuels, organic chemicals and plastics), whereas exports from China to Saudi Arabia comprise industrial commodities, electrical equipment (around 70\%), machinery, furniture, clothing and footwear. Lowering trade barriers could offer greater benefits for both countries. According to a recent KAPSARC study, the elimination of import duties for selected plastic products would lead to $\$ 410$ million in incremental annual sales from the GCC to China and would also result in a $\$ 242$ million benefit to Chinese consumers (Galkin et al. 2018). Saudi Arabia would be the largest GCC beneficiary of this policy.

Saudi Arabia is increasingly diversifying its industrial structure and exports, including exporting a wider

Figure 3. Exports from Saudi Arabia to China.

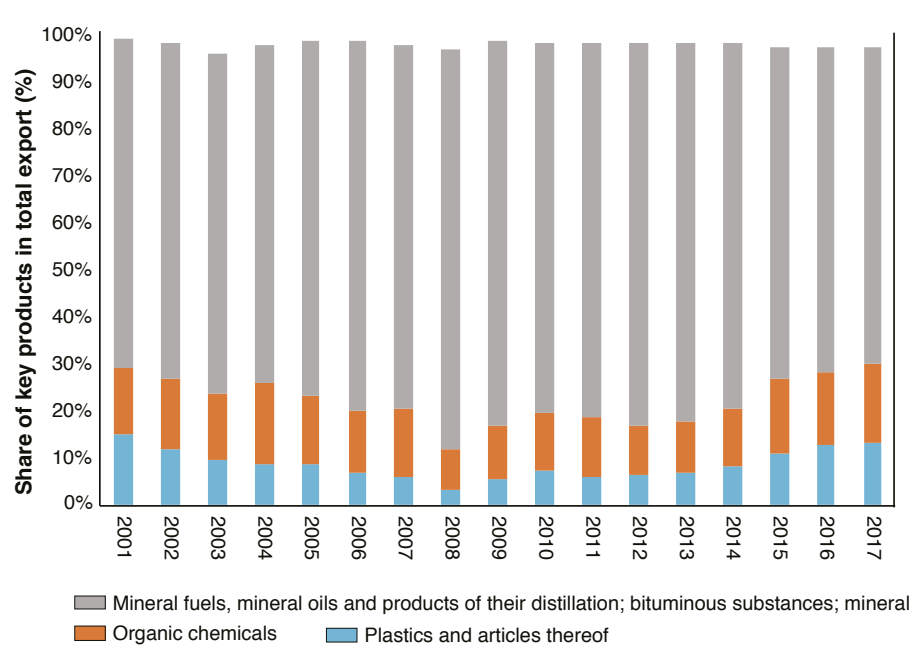

Source: KAPSARC, based on ITC (2018). range of non-oil related commodities. This trend will change trade relations between Saudi Arabia and China. The trading facilities that Saudi Arabia has established with MENA countries, Singapore and the European Free Trade Association should help extend the global market for the new manufacturing capacity scheduled to be built under Vision 2030 and the BRI.

\section{FDI interdependence}

FDI interdependence measures the dependence of one economy's FDI inflows or outflows on another economy. It can be calculated as the proportion of an economy's FDI inflows from another economy, while the outflows dependence is calculated as the proportion of an economy's FDI outflows to a particular economy (Capannelli et al. 2009; BFA 2018).

Figure 4. Exports from China to Saudi Arabia.

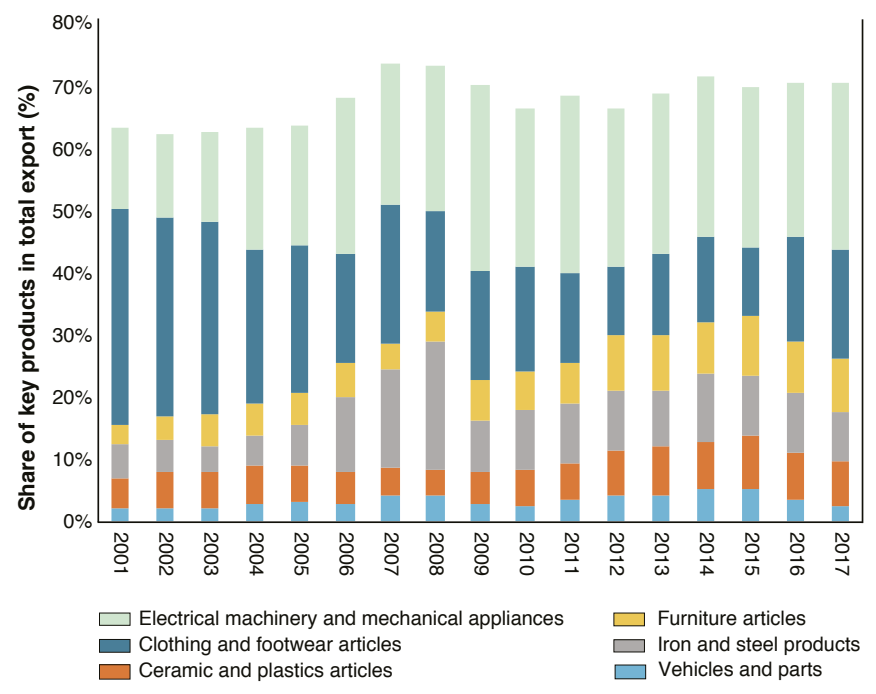

Source: KAPSARC, based on ITC (2018). 
Figure 5. FDI flow interdependence between China and Saudi Arabia.

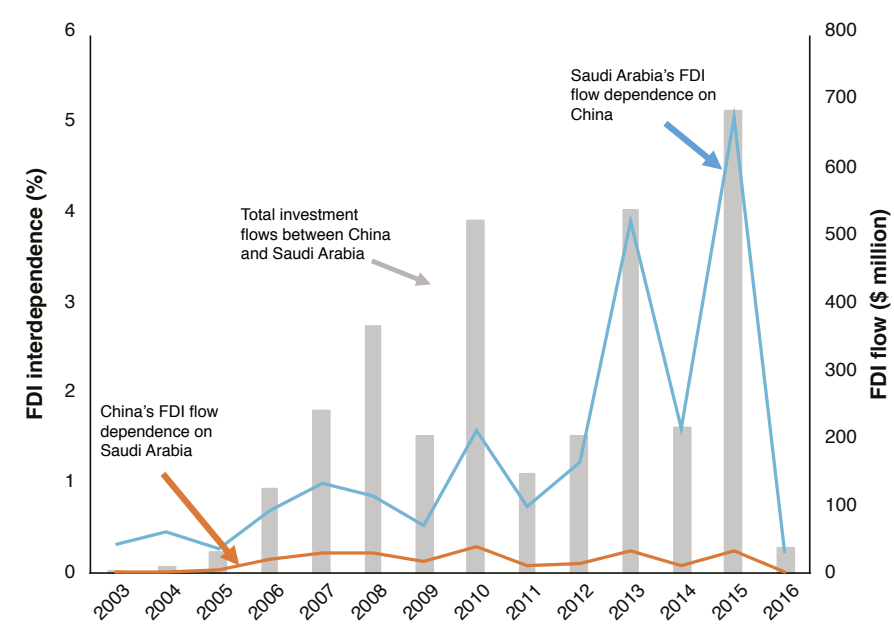

Source: KAPSARC, based on CEIC and UNCTAD.

Total investment flows between China and Saudi Arabia increased more than twentyfold from 20052015, while the FDI flow interdependence between China and Saudi Arabia present a very different trajectory in China and Saudi Arabia. As shown in Figure 5, Saudi Arabia's dependence on China grew from $0.3 \%$ in 2003 to $5 \%$ in 2015, while China's dependence on Saudi Arabia remained at around $0.2 \%$ over the same period. This can be mainly attributed to a relatively small fraction of Saudi Arabia's investment in global inward FDI flow to China. However sharp growth in investment from China to Saudi Arabia from 2010 (Figure 6) and declining global inward FDI flow to Saudi Arabia since 2009 (Figure 7) have enlarged the difference in interdependence of FDI flow.

The inward FDI flow is vital if Saudi Arabia is to achieve its targets of increased employment, economic diversification and knowledge creation. Vision 2030 aims to increase the contribution of inward FDI to gross domestic product (GDP) from $3.8 \%$ in 2016 to $5.7 \%$ by 2030 , estimated to be the equivalent of $\$ 95.6$ billion on an annualized basis (Jadwa Investment 2016). The Kingdom has drawn
Figure 6. FDI flows between China and Saudi Arabia.

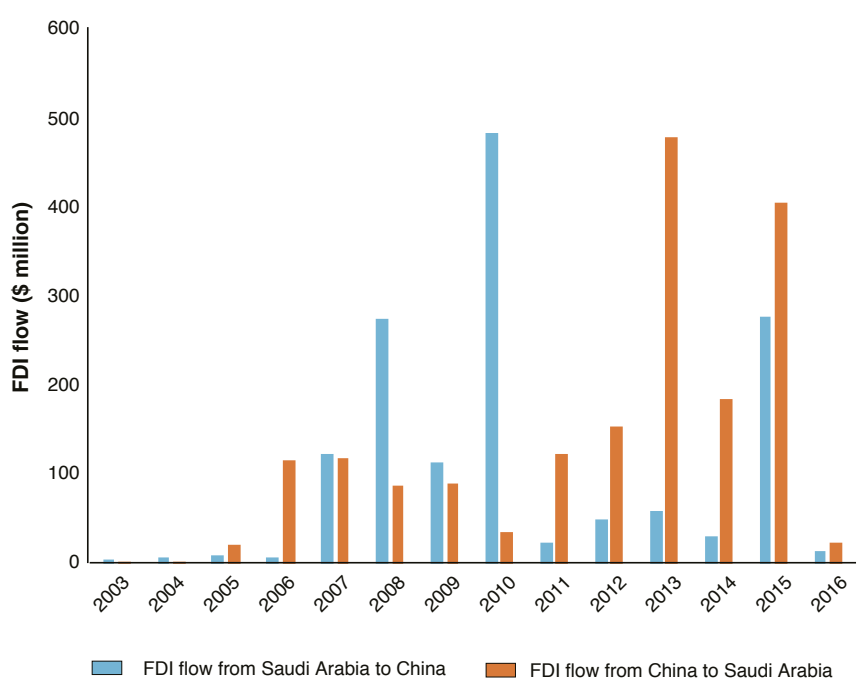

Source: KAPSARC, based on CEIC and UNCTAD.

up plans to attract more inward FDI, including building new cities, opening up additional sectors of the economy, extending the licensing period for foreign investors, and loosening the restrictions on foreign ownership of companies listed on the Saudi stock exchange. The Saudi government has also invested heavily in infrastructure to improve the business environment in the Kingdom.

Saudi Arabia experienced a boom in FDI flows from 2005-2008. However, the drop of FDI inflows to Saudi Arabia since 2009 suggests a more challenging situation for the country. In 2017, the FDI inward flow fell to a level not seen in the past decade and was about 80\% lower than in 2016 (Figure 7). The escalation and broadening of trade tensions could negatively affect investment in global value chains. The significant international divestments that occurred in 2017 and the negative intracompany loans by multinationals were the main contributors to this decline (UNCTAD 2018). For example, oil major Shell sold its $50 \%$ stake in the petrochemicals joint venture (SADAF) to its partner Saudi Basic Industries Corporation (SABIC) for $\$ 820$ million in August 2017. Because of its comparatively large 
population and big state budget deficit, Saudi Arabia had to introduce more severe austerity policies than other GCC countries whose economies were also negatively affected by the decline in oil prices.

China's outward FDI flows grew quickly to a record high in 2016, before declining by $36 \%$ to $\$ 124$ billion in 2017 (Figure 8). This can be attributed to Chinese regulations restricting outward direct investment (ODI), which aimed to counter the Chinese yuan's depreciation, tackle corruption, and address a domestic real estate bubble. Restrictive investment screening procedures in major advanced economies have also negatively impacted its outward FDI flows. In recent years, bodies and countries including the European Commission, Australia, France, Germany, the United Kingdom and the United States (U.S.) have either been discouraging foreign acquisitions or have been considering tightening the screening procedures for foreign investment in the science and technology sector.

Given the changing environment for global trade and investment, there is significant potential to divert and

Figure 7. Global inward and outward FDI flow for Saudi Arabia.

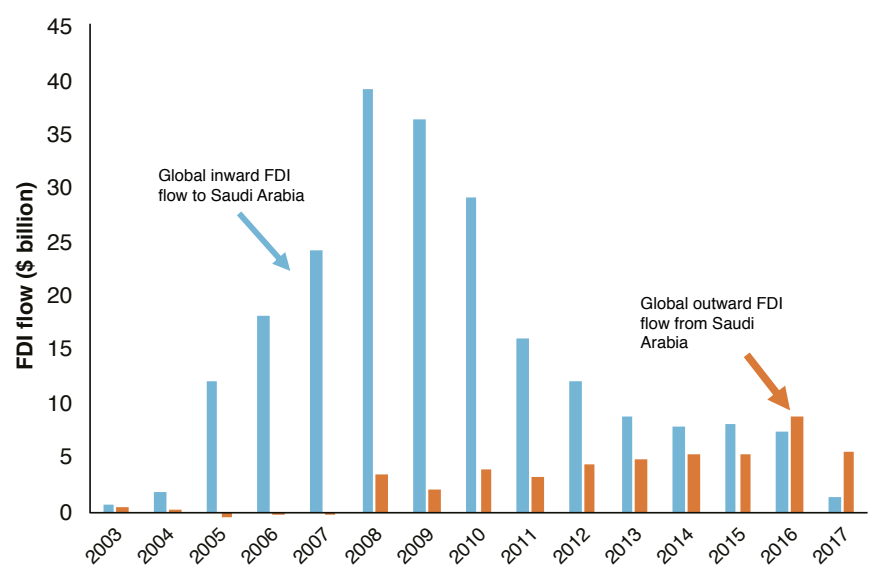

Source: KAPSARC, based on UNCTAD. increase China's investment in Saudi Arabia and BRI countries. China has rapidly increased its direct investment in the countries and regions covered by the BRI, from $\$ 910$ million in 2005 to $\$ 19.56$ billion in 2015 (CDB et al. 2017). This investment is only a modest proportion of the total foreign investments in these countries. There remains significant potential for future collaboration between China and Saudi Arabia.

A more open Chinese market will also create more opportunities for Saudi Arabia to invest in China. China recently revised its foreign investment exemption list for 11 free trade zones, lifting investment restrictions in a number of industries (UNCTAD 2018). Beijing also issued an updated version of its Investment Industry Guidance Catalogue, which reduced the number of restrictive measures for foreign investment from 93 to 63 and included more services, manufacturing and mining. In April 2018, China announced a timeline for liberalizing its automobile and financial industries. These policy changes should create opportunities for Saudi Arabia to grow its Public Investment Fund (PIF), which aims to become one of the largest sovereign wealth funds in the world, to help facilitate Saudi Arabia's economic diversification.

Figure 8. Global inward and outward FDI flow for China.

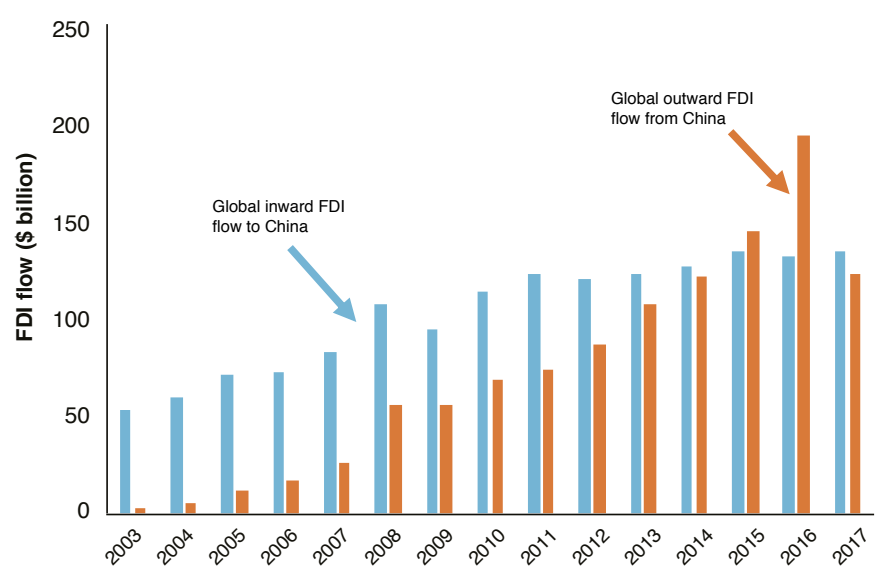

Source: KAPSARC, based on UNCTAD. 


\section{Financial integration}

Increasing trade and investment, funding ambitious infrastructure plans and industrial development cannot be achieved without the support of the financial services industry. In order to meet its targets the BRI will require trade financing, infrastructure financing, insurance services and currency settlement services (CDB et al. 2017). Trade finance usually includes lending, letters of credit, export credit, factoring, credit insurance, and cross-border supply chain finance. Infrastructure projects are often complex and involve a large number of parties. In addition to government funds, it is increasingly important to mobilize new sources of private or commercial funding and to use a diverse range of financial instruments, such as bonds for pension funds and insurance companies and guarantees or mezzanine capital for development banks and export credit agencies (Ehlers 2014). The higher risk involved in doing business in new markets also requires the use of insurance services such as overseas investment insurance and export credit insurance.

Multilateral financial institutions, such as the Asian Infrastructure Investment Bank (AllB), the Asian Development Bank, the World Bank and the Silk Road Fund (Box 1), have expedited cooperation between China and Saudi Arabia in developing green finance guidelines and supervising finance operations.

Progressive collaborations have also been achieved in:

Improving the exchange of financial information: China and Saudi Arabia joined the Common Reporting Standards (CRS) Multilateral Competent Authority Agreement and committed to the first exchange of financial accounts by September 2018. The CRS requires certain financial institutions such as banks, brokers, funds and some insurance companies and custodial institutions to amend their due diligence and tax reporting procedures.
Extending the banking industry's service: The National Commercial Bank of Saudi Arabia established its first office in Shanghai in 2013, with the aim of helping Saudi enterprises invest in China's economic development. The Industrial and Commercial Bank of China established its first branch in Riyadh in 2015 to facilitate Chinese projects in the Kingdom.

Establishing multilateral development financial institutions: In 2016, Saudi Arabia joined the China-led AllB as one of its 57 founding members. The AllB was the first Asia-based international bank focusing on infrastructure construction and green financing.

Establishing a joint investment fund: Saudi Arabia and China have established a jointly operated $\$ 20$ billion investment fund, sharing costs and profits on an equal basis. The fund will provide financing support mainly for infrastructure, energy and mineral resources developments.

Exploring new ways of fundraising: Closer ties between China and the Kingdom may also extend to international debt markets. For example, Saudi Arabia's PIF is considering issuing panda bonds in China to help cover its budget deficit and finance major investment projects in the hope of expanding its economy and creating jobs. Panda bonds are yuandenominated bonds from non-Chinese issuers that are sold within China.

The strategic cooperation between both countries still requires a lot more development under the $\mathrm{BRI}$ and Vision 2030 frameworks. The rapid development of new economic and industrial cities in Saudi Arabia has presented more opportunities for infrastructure financing cooperation. However, there is often a mismatch between infrastructure 
investment demand and the supply of infrastructure finance. Infrastructure investment has the potential to be very profitable for the economy as a whole, but it is especially sensitive to market conditions (Ehlers 2014). Infrastructure projects are usually characterized by being relatively illiquid, with a high initial cost and long payback period, and are particularly sensitive to policy and political changes, while government funding often falls short of projects' budgetary needs. It is preferable to mobilize funds from a mixture of financial instruments or through public-private partnerships, so as to transfer the risks to a broader group of investors and increase efficiency gains.

Including the Chinese yuan as a currency for financial settlement is another topic under discussion. This may need increased financial infrastructure connectivity, regulatory coordination, and the framework design for cross-border monetary and financial cooperation. China has signed bilateral currency-swap agreements with the central banks and monetary authorities of 35 countries and regions, including $21 \mathrm{BRI}$ states (CDB et al. 2017). The inclusion of Chinese yuan into the International Monetary Fund's Special Drawing Right currency basket in 2015 signaled a milestone in the integration of the Chinese currency into the global system. These efforts have expanded the use of Chinese yuan in cross-border settlement and investment among the BRI countries. In April 2018, Chinese yuan settlements reached $14.6 \%$ of China's total trade settlements (Chan and Teo 2018). The yuan's internationalization will be a long-term and gradual process, requiring careful domestic financial liberalization and capital account opening while maintaining stable economic growth and credit conditions (Overholt 2017). There is still a perceived risk in Saudi Arabia of diversifying the central bank's reserves to include Chinese yuan (Rashad 2014).

\section{Box 1: New financing institutions: Silk Road Fund}

The Silk Road Fund was officially established on Dec. 29, 2014, in Beijing, with investment from the State Administration of Foreign Exchange, China Investment Corporation, China Development Bank and the Export-Import Bank of China. The fund's aim is to promote the integration of development projects between China and project host countries and to invest in a broad spectrum of sectors under the BRI framework, including infrastructure, resources and energy development, industrial capacity cooperation and financial cooperation.

The fund's capital comprises $\$ 40$ billion and 100 billion yuan (equivalent to about $\$ 15$ billion at time of writing). It works with international development organizations and domestic and overseas financial institutions for joint investment and also manages entrusted assets. As of March 2017, the fund had concluded contracts worth about $\$ 6$ billion. The fund monitors potential risks in BRI member countries and applies risk management, from project screening to post-investment project operation.

During President Xi Jinping's January 2016 visit to Saudi Arabia, the Silk Road Fund and Saudi Arabia's ACWA Power signed an MOU to jointly develop and invest in power projects in the United Arab Emirates (UAE), Egypt and other MENA region countries, representing the Silk Road Fund's first step toward investment cooperation in the MENA region. 
On July 22, 2018, the Silk Road Fund signed an agreement with the Dubai Electricity and Water Authority (DEWA) and ACWA Power to jointly invest and develop the 700 megawatt DEWA Concentrated Solar Power (CSP) project in the UAE. The CSP project will be the fourth phase of the Mohamed bin Rashid Solar Park in Dubai, which will be the world's largest single-site solar power plant when completed.

Source: Silk and Road Fund.

\section{People-to-people exchanges}

Being open to global economic activity allows companies and economies to benefit from competition, the flow of ideas, best practices and personal connections (Manyika et al. 2015). Intraregional labor migration is driven by the expanding divergence between countries' economic development, incomes, population dynamics, skill imbalances, and policies designed to regulate the flow of people from suppliers to recipients of labor flows (Capannelli et al. 2009). Education and economic development are linked via the labor market. Education could be a powerful people-to-people enabler, creating opportunities for balanced human development among BRI countries (CDB et al. 2017). In addition, tourism has proven to be an effective instrument for cultural exchange, boosting the development of new economies.

Because of the differences in political and economic structures and demography dynamics between China and Saudi Arabia, migration has mostly been in one direction - from China to Saudi Arabia. Therefore, this paper only focuses on labor and tourist flows from China to Saudi Arabia, while educational and cultural exchanges are more two-directional.

The construction projects outlined in Vision 2030 have the potential for collaboration in contracting and labor services. Under the 2008 ChinaSaudi Arabia framework agreement to strengthen cooperation on infrastructure construction, 39
Chinese engineering and construction enterprises recommended by the Chinese government were permitted to conduct business in Saudi Arabia through a fast-track process (Gong 2017). In 2016, 139 construction contracts in Saudi Arabia with a value of more than $\$ 5$ billion were awarded to Chinese enterprises (MOFCOM 2017). These projects spurred significant growth of labor flows from China to Saudi Arabia (see Figure 9). But the implementation of a new levy on expatriate residency and Saudi Arabia's 'Saudization' employment policy will likely increase challenges to profit margins and labor flows.

Educational exchanges not only help incubate expertise for economic collaboration but also help to build trust between citizens. More than 1,000 Saudi students go to study in China every year (Xinhua Net 2018). More than 270 Chinese students are enrolled at Saudi universities and the largest single foreign representation at the King Abdullah University of Science and Technology is of Chinese nationals (Rakhmat 2014). Scholarship programs have played a key role in facilitating such educational exchanges. In 2006, Saudi Arabia launched a scholarship program for Saudi students applying to study in China and in some other East Asian and South Asian countries. In 2015, China announced plans to expand student exchanges and promote educational cooperation, providing 10,000 government-funded scholarships annually for students from other BRI countries to study in China and sending 2,500 government-funded Chinese 
Figure 9. Labor flows from China to Saudi Arabia.

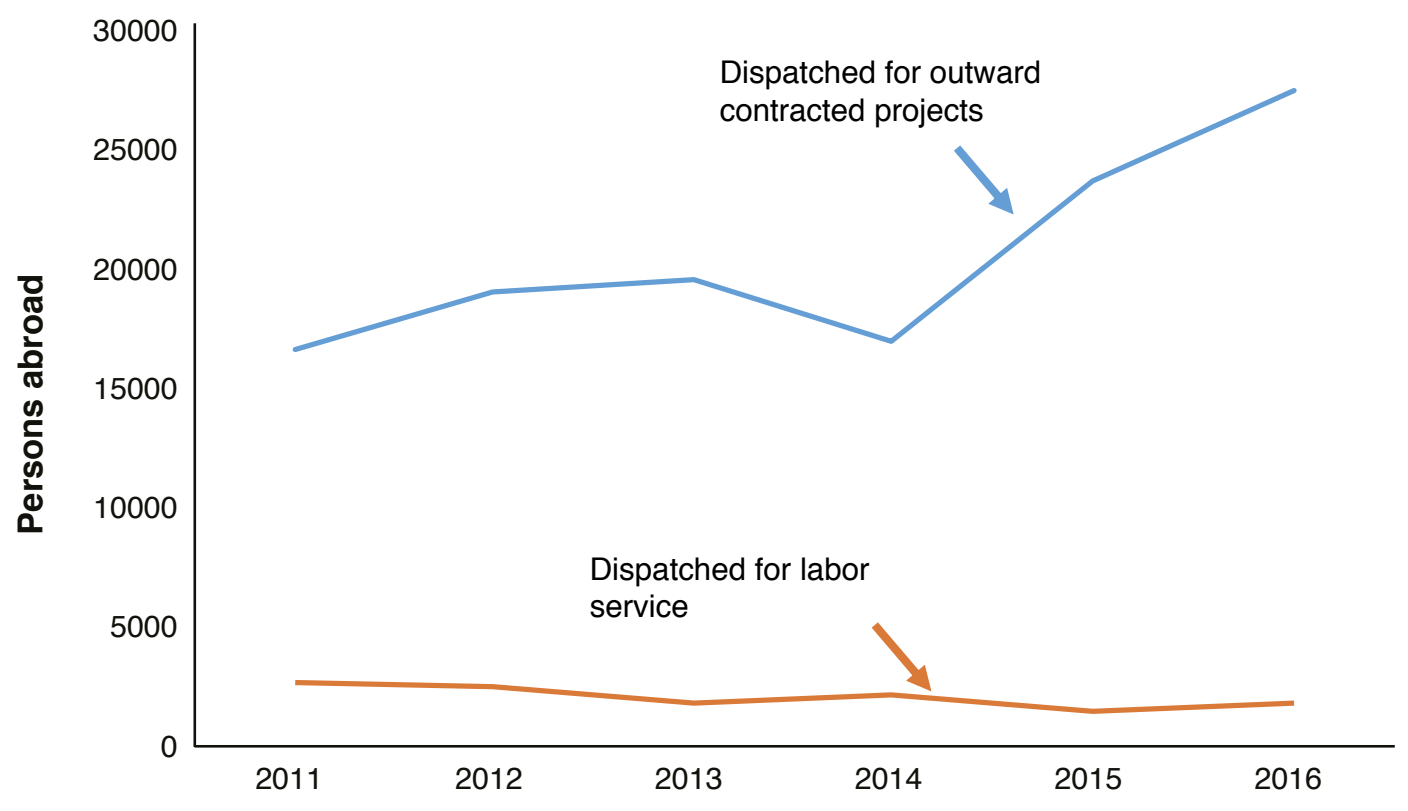

Source: KAPSARC, based on China National Bureau of Statistics.

students annually to study in other BRI countries. In total, 279 Chinese universities offer academic programs for overseas scholarship recipients.

Cultural exchanges between the areas now called China and Saudi Arabia can be traced back over 2,000 years when trade caravans from both regions traveled along the ancient Silk Road. Envoys from the Arab Empire visited China during the Tang Dynasty. Zheng He, China's Muslim navigator in the Ming Dynasty (618-907), sailed to Jeddah, Mecca and Medina, among other destinations. The Silk Road treasure ship built by the Kingdom for the 2010 World Expo in Shanghai, China's participation in the 2013 Jandriyah festival in the Kingdom and a series of reciprocal exhibitions showcasing the two countries' cultures from 2016-2018 signal the growing frequency of cultural exchanges since both countries established strategic and friendly relations in 2008.

Tourism from China has the potential to boost tourism in Saudi Arabia greatly. The growing incomes of Chinese households, more relaxed visa policies, increased convenience of travel services, and improved air links have stimulated Chinese overseas leisure travel and contributed to economic growth for many tourist destinations around the world (Box 2). China generated overseas tourist spending of $\$ 115$ billion in 2017, from more than 131 million overseas trips (CTA and Ctrip 2018). It has been forecasted that by 2028 some 29 million international tourists will have visited Saudi Arabia, spending some $\$ 20$ billion. The contribution of travel and tourism, including the wider effects of investment, the supply chain and induced income impacts, is forecast to contribute $\$ 106$ billion to Saudi GDP by 2028 , up from $\$ 64$ billion in 2017, and to support 1.5 million jobs by 2028, up from 1.1 million in 2017 (WTTC 2018). Achieving these figures will largely depend on the progress of policy implementation, including easing visa requirements, developing tourist infrastructure, empowering tourism agencies, and upgrading the training of Saudis employed in the tourism sector. 


\section{Box 2. Growing the economy with tourist flows from China}

In 2011, Australia launched China 2020, a strategic plan to increase tourism from China. The plan identified 600 potential cities in China and took a segment-specific approach to designing and marketing its tourism products via targeted channels such as popular Chinese social media networks. Australia also introduced electronic visa applications and a quick review process for Chinese tourists and began issuing 10-year tourist visas. As a result Australia now hosts 1.2 million Chinese visitors annually, tourists who are expected to spend over $\$ 9.3$ billion a year in Australia by 2020 .

Japan published its National Building Tourism Strategy in 2003, with Northeast Asia, including China, as its primary target from which to attract tourists. Japan promoted its tourism sector by easing both its visa and tax-free shopping policies. Japan also worked with Chinese travel companies to develop tourism packages targeting Chinese customers. As Chinese tourists prefer mobile payment systems, Japan also promoted mobile payment technology in major tourism destinations. The strategy proved very successful: in 2015, 4.99 million Chinese tourists visited Japan, with China overtaking South Korea as Japan's largest source of international tourists.

Source: UNWTO (2017). 


\section{Identified Strategic Areas for Cooperation}

\section{Energy is still the core area of cooperation}

Saudi Arabia has historically been China's biggest oil trading partner, although in 2016 Russia surpassed the Kingdom as China's largest source of foreign crude oil, exporting 1.2 million barrels per day (MMbbl/d) to China in 2017 compared with Saudi Arabia's $1 \mathrm{MMbbl} / \mathrm{d}$ (EIA 2018). China imported 8.4 MMbbl/d crude on average in 2017. New refinery capacity and strategic inventory stockpiling, combined with declining domestic oil production, are the main factors contributing to rising Chinese crude oil imports, a trend which is set to continue out to 2030 (Sinopec 2018; Wang 2018). This section lays out the basis of energy cooperation between China and Saudi Arabia.

The ' $1+2+3$ ' model illustrated the collaborative framework between China and Saudi Arabia and a change to the traditional paradigm of China's foreign energy strategy, which was to ensure supply security through imports and direct investment. At the same time, Saudi Arabia is moving away from being a heavily oil-dependent economy toward becoming a diversified economy. Given these changes, energy cooperation between the $\mathrm{BRI}$ and Vision 2030 is expected to evolve in the following ways:

From one-sided bilateral limited energy cooperation to two-way multilateral and multilevel energy cooperation.

From building a regional energy cooperation mechanism to building regional and international energy governance mechanisms.

From an emphasis on traditional fossil energy cooperation to prioritizing green low-carbon energy and the whole energy value chain.
From individual planning to joint planning and the promotion of cooperative projects.

From government-led cooperation dominated by state-owned enterprises to market-driven cooperation with active participation from both state- and privately-owned enterprises.

The interests of Saudi Arabia as an oil exporter and of China as an oil importer might differ in the short term, but for long-term sustainability, China and the Kingdom have a common interest in maintaining regional market stability. Both countries have expressed the will to establish an oil reserve facility, to develop oil and transport technologies, and to integrate their petrochemical production supply chains (Saudi Aramco 2016).

China has the world's largest energy service company (ESCO) market, valued at $\$ 56$ billion in 2016. Saudi Arabia recently formed a $\$ 500$ million ESCO focused on public buildings (Chen et al. 2018a). There is potential to extend the collaboration and improve the Kingdom's industrial energy productivity, with industry accounting for over $50 \%$ of energy consumption in both countries. Areas for the exchange of knowledge and experience could include: how differential industrial energy pricing can support energy efficiency, benchmarking, establishing a market for industrial energy efficiency service companies, and how to build competitive high-value ecosystems (Chen et al. 2018b).

The economic viability of renewable energy in Saudi Arabia is clear given the Kingdom's year-long high solar intensity, the untapped potential of its geothermal and wind resources, and the potential to convert waste to energy. Saudi Arabia aims to build 9.5 gigawatts (GW) of renewable energy (RE) capacity, or $10 \%$ of all its power generation, 
by 2023 and recently outlined plans for up to 200 GW by 2030 . The National Renewable Energy Program eProcurement Portal offers a gateway to participate in the Kingdom's RE transition. As the world's largest producer and installer of RE technologies, China's experience could be of great value to Saudi Arabia's policy framework design. The two countries may choose to collaborate on areas including jointly investing and developing the Kingdom's RE market, transferring technologies and skills, and building local production capacity. For example, the technology behind concentrated solar power systems is still at the development stage and not yet ready for large-scale commercialization. However, this technology fits with the Kingdom's need for desalination, industrial applications, and thermal energy storage for power generation at night. As such, there is potential for joint research and development between the two countries.

\section{Integrating petrochemical industry supply chains}

The Saudi petrochemical and chemical industries are a key part of the Kingdom's economy. Saudi Arabia remains the largest chemicals producer in the GCC region, accounting for $67 \%$ of GCC members' chemicals output. Saudi exports of chemical and plastic products were valued at around $\$ 28$ billion in 2016 , comprising $60 \%$ of the country's total nonoil exports (SIDF 2018). The Kingdom's chemical capacity rose from 44.3 million metric tonnes per annum (mtpa) in 2006 to 106.7 million mtpa in 2016 a 140\% increase (GPCA 2017). However, the sector faces a number of challenges, including the decline in international chemical prices since mid-2014, the rising price of domestic feedstocks resulting from the energy reform, and more intensive global competition (Jadwa Investment 2017). To remain competitive, analysts suggest Saudi Arabia could upgrade its management and technical capabilities, extend the integration of production assets across the chemical value chain, and improve access to global markets.

Increasing the value and competitiveness of Saudi Arabia's chemicals industry has led to several government and business initiatives. The Petrochemical Technology Strategy Plan involves key stakeholders investing in technology development, localization and transfer. The National Industrial Cluster Development Program (NICDP) has been tasked with rebuilding the plastics supply chain and with establishing expertise in plastics processing and conversion technology. The plastics, rubber and packaging cluster will play a fundamental role in developing other industry clusters such as the automotive, biomedical and energy industries. Saudi Aramco, which has traditionally led the development of the Kingdom's oil and gas sector, has now moved into the chemical sector. Its joint venture with Dow Chemicals, the first petrochemical complex in the GCC to use naphtha as liquid feedstock, is designed to produce a variety of new downstream products (Jadwa Investment 2017). And Aramco's takeover of SABIC, intended to develop a fully integrated complex from crude oil to chemicals, signals an important move, following the strategy to increase the value-added from polymers for the Saudi economy (Figure 10).

China's market growth provides the potential for integrated cooperation along the supply chain with Saudi Arabia. China's petrochemical capacity grew sixfold between 2000 and 2014, representing 64\% of global capacity growth during this period (GPCA 2015). Ethylene and methanol production capacity in China has outpaced growth in the GCC and China's polypropylene production capacity is triple the GCC's output (GPCA 2017). Despite efforts to increase its self-sufficiency, China remains a large importer of key plastics. In 2016, China imported about 14.5 million metric tonnes of chemicals from the GCC, accounting for one-third of GCC chemical exports to Asia. Basic/ intermediates and polymers dominate these exports. 
Figure 10. Increasing value for the Saudi Arabian petrochemical industry.

\section{Historic Saudi polymers portfolio}

$\begin{array}{ll}\text { Commodity polymers } & \text { Elastomers } \\ \text { Polyethylene } & \\ \text { Polypropylene } & \text { SBR } \\ \text { Polystyrenes } & \text { PBR } \\ \text { PVS } & \text { EPDM } \\ \text { PET } & \text { TPE, TPO } \\ & \text { Carbon Black }\end{array}$

\section{The present portfolio}

\author{
Engineering polymers \\ EVA \\ Polycarbonate \\ POM \\ Nylon 6, 66 \\ ABS \\ PMMA \\ $\mathrm{PU}$ \\ TDI, MDI
}

Increasing value-added for the Saudi Arabian economy

Source: IC (2018).

Aligned business investment in higher value chemical production could help both China and Saudi Arabia move beyond a zero-sum game. A planned $\$ 3.8$ billion polyester manufacturing complex at Jazan is set to be the first wholly foreignowned petrochemical project in the Kingdom. The project, with investment from Pan-Asia PET Resin (Guangzhou) Co., one of the top three polyethylene terephthalate (PET) bottle suppliers in China, will benefit from being close to raw material supplies, with a large paraxylene facility under construction by Saudi Aramco nearby. The Jazan complex has been designed to produce 2.5 million metric tonnes $(\mathrm{mt})$ of purified terephthalic acid (PTA), 1 million $\mathrm{mt}$ of PET, and 200,000 mt each of polyester engineering plastics, thin film, and polyester fiber (China Daily 2017). Currently, Saudi Arabia has no PTA production and the Middle East overall imports 3 million mt of PTA annually, mainly from East Asia.

Coordinated efforts between governments and businesses can accelerate integration into the global market. An example can be found in the partnerships that two Chinese provinces, Guangdong and Ningxia, have established with the Royal Commission of Jubail and Yanbu (RCJY) and Saudi Aramco, to create an independent entity which will build and operate the industrial park in Jazan. Similar partnerships are also under development between Saudi Aramco and some Chinese provinces. In Fujian province, the government's Free Trade Zone Initiative and the construction of a chemical hub provide an opportunity for Saudi Aramco to upgrade its downstream chemical business in China. In Yunnan province, the expansion of petrochemical facilities proposed by Saudi Aramco and China National Petroleum Corporation also fits into the local government's plan for industrial upgrading.

The integration of petrochemical supply chains could be further enhanced by the free trade agreement (FTA) between China and the GCC. Negotiations between the GCC and China started in 2004 but were suspended in 2009. During President Xi's January 2016 visit to Saudi Arabia, the GCC announced the resumption of its FTA negotiations 
with China. An FTA could present significant mutual benefits for China and Saudi Arabia. Based on the analysis of three petrochemical/polymer product groups, namely low-density polyethylene, highdensity polyethylene, and polypropylene, Galkin et al. (2018) concluded that the elimination of import duties on those three products would lead to incremental annual sales from the GCC to China of $\$ 410$ million. A zero-tariff regime for plastics products would also result in net welfare gains for China and a \$242 million benefit to Chinese consumers from the trade creation effect. Saudi Arabia would be the largest beneficiary among the GCC member states, even though the estimated effects vary significantly across products.

\section{From construction to industrial development}

Construction of infrastructure, real estate, industrial, retail and hospitality facilities in Saudi Arabia would create the strongest driver for economic growth in the country. It is estimated that about $\$ 4$ trillion of investment will be needed to double the Kingdom's GDP by 2030, of which $\$ 2$ trillion, in real terms, would be spent on construction (Al-Kibsi et al. 2015). Most of these projects are connected with the construction of the new NEOM smart city and new industrial cities including Jazan, Ras Al-Khair and Al-Hasa.

Big construction projects can stimulate the development of a wide range of industries, from basic materials' manufacturers and suppliers to electrical and mechanical machinery manufacturing. These present a lot of potential for collaboration between China and Saudi Arabia. China is the largest global producer of more than 210 industrial products (Chen et al. 2018b). In addition, the Made in China 2025 plan shows the country's ambition to upgrade its manufacturing capacity from large-scale production to high-tech production. The knowledge and capacity that China has accumulated through the development of its manufacturing industry can be transferred as local content for the Kingdom's new phase of economic growth (Zhang et al. 2016).

Saudi Arabia's significant mineral resources and its rapidly growing construction sector make its basic materials industries competitive. Steel, aluminum, and cement are the sectors that can most clearly benefit from increased construction activity. It has been estimated that Saudi steel demand could grow from 13.5 million $\mathrm{mt}$ in 2012 to as much as 25 million $\mathrm{mt}$ by 2030, given the predicted growth in the Kingdom's construction, oil and gas, and manufacturing sectors. This offers Saudi Arabia the opportunity to add between 15 million $\mathrm{mt}$ and 20 million $\mathrm{mt}$ of new crude steel capacity to meet rising domestic demand (Al-Kibsi et al. 2015).

Saudi Arabia also has a number of structural advantages that could enable it to grow the automotive, electrical and mechanical machinery sectors. For example, as Figure 11 shows, developing the country's automotive industry could provide a significant economic stimulus, building on Saudi Arabia's strength in upstream materials production. The Kingdom is a major consumer of cars and trucks, all of which are currently imported. Almost 1.6 million vehicles were sold in the GCC in 2016, of which half were sold in Saudi Arabia, highlighting the potential of the Kingdom to become a regional automobile production hub and key component manufacturing center. Several major projects producing heavy-duty vehicles have recently been implemented in the Kingdom, with production capacity expected to reach 39,000 trucks per year by 2022 (IC 2018).

Unlocking the economic potential of construction projects and new industrial capacity requires innovative collaboration. Profit margins in the Saudi 
construction sector are relatively small, averaging about $5 \%$ to $7 \%$ in 2015 , despite the extensive use of low-cost foreign laborers (Al-Kibsi et al. 2015). To improve the productivity of construction projects, Chinese enterprises have created a business model integrating project management, financial capacity, construction qualification, and machinery and equipment supply (Bao 2018). Within this model, business players with different strengths can coordinate and support each other so as to overcome constraints, such as a lack of funding, technology and human resources.

Creating industrial parks as part of urban development is another approach being followed in
Saudi Arabia. For example, China and Saudi Arabia established a joint venture in the Jazan Economic City to develop and operate a Chinese industrial park with the aim of manufacturing electrical equipment, petrochemicals and automotive components, as well as setting up food processing and heavy industries (Box 3). Chinese companies and their local counterparts are working in tandem to improve the division of labor and distribution of industrial chains by encouraging related industries to develop together with the park. In the long run, facilitating access to intermediate goods and raw materials from local suppliers would help maximize the economic benefits from promoting the linkages between industrial parks and urban master planning.

Figure 11. Building an automotive value chain in Saudi Arabia.

\begin{tabular}{|c|c|c|}
\hline \multicolumn{3}{|l|}{ Upstream } \\
\hline $\begin{array}{ll}\text { - } & \text { Metals } \\
\text { - } & \text { Fuel } \\
\text { - } & \text { Mining } \\
\text { - } & \text { Plastics } \\
- & \text { Rubber } \\
\text { - } & \text { Glass } \\
- & \text { Electronics }\end{array}$ & $\begin{array}{l}\text { Original equipment } \\
\text { manufacturers (OEM) } \\
-\quad \text { Commercial vehicles } \\
-\quad \text { Passenger vehicles } \\
-\quad \text { Two-wheelers } \\
-\quad \text { Three-wheelers } \\
\text { Component Manufacturers }\end{array}$ & $\begin{array}{l}\text { Downstream } \\
\qquad \begin{aligned} \text { - } & \text { Finance } \\
\text { - } & \text { Insurance } \\
\text { - } & \text { Sales \& service } \\
\text { - } & \text { Car rentals } \\
- & \text { Fuel supply } \\
\text { - } & \text { Advertising } \\
\text { - } & \text { Transportation \& } \\
& \text { logistics }\end{aligned}\end{array}$ \\
\hline
\end{tabular}

Source: IC (2018). 


\section{Box 3: Chinese Industrial Park in Jazan City}

Jazan City for Primary and Downstream Industries (JCPDI) is being developed as part of the BRI and Saudi Vision 2030 strategic partnership between China and Saudi Arabia and will provide a unique development zone for Chinese investors.

In 2016, the Royal Commission for Jubail and Yanbu (RCJY), Saudi Aramco, and Guangdong and Ningxia provinces agreed to establish a joint venture company in JCPDI. The joint venture, Saudi Silk Road Industrial Services, will focus on attracting Chinese investments and providing industrial services in a special development zone covering 30 square kilometers $\left(\mathrm{km}^{2}\right)$ of industrial land and $2 \mathrm{~km}^{2}$ of residential space within the JCPDI. It is designed to accelerate the Kingdom's industrialization process through integrating the technologies, manufacturing capabilities and investment resources of two Chinese partners from Guangdong and Ningxia provinces. Jazan is strategically located, equipped with world-class infrastructure connecting European, African and Middle Eastern markets. The Saudi Silk Road joint venture plans to build production capacity in electrical equipment, petrochemicals, automotive spare parts, food processing and heavy industries in the JCPDI.

As first mover to this project, Pan-Asia PET Resin (Guangzhou) Company, one of the top three PET bottle suppliers in China, said it planned to invest $\$ 3.8$ billion and build a polyester manufacturing complex in Jazan. In March 2017, RCJY signed an agreement with Pan-Asia PET Resin, allocating industrial land to the Jazan petrochemical plant and committing to provide funds from the Saudi Industrial Development Fund.

The development of the Chinese Industrial Park in Jazan was further promoted as an important topic for the Saudi-Chinese Investment Forum, jointly hosted by Saudi Arabia's Ministry of Energy, Industry and Mineral Resources and China's National Development and Reform Commission in Jeddah in 2017. Over 300 representatives from the energy, infrastructure, and financing sectors joined the discussion and explored the partnership and investment opportunities that bridging the BRI and Vision 2030 could bring. 


\section{Closing the Gap: Actions to Help Achieve the Goals}

he Saudi-China partnership has made significant progress over the past decade. To accelerate cooperation, this paper has identified five steps that could help translate the complementary advantages into joint benefits.

\section{Define a bridging strategy for implementation}

Both China and Saudi Arabia have clear strategies to achieve their short- and long-term objectives, respectively, but both sides need to define a bridging strategy for implementing these plans. This strategy could include:

Linkages with national investment policies, including incentives for foreign investment that incorporate key technologies, talent and skills initiatives, and improving the embeddedness of businesses in recipient countries.

Linkages with national trade policies that emphasize trade facilitation for greater economic gain from integrated global supply chains.

Balancing the requirements of local content and the needs of business to generate growth, especially in transition periods.

\section{Build a capacity system for BRI engagement}

The Saudi-Chinese High-Level Joint Committee and six sub-committees established the official working mechanism to plan and coordinate cooperation annually. This structure helps the counterparts at the national leadership level to reach agreements, but more effort is needed to actively and regularly engage with players in the BRI. This could include:

Coordinating BRI-related investment and initiatives among different Saudi government departments on a regular basis.
Building a focal point in the Kingdom to interact with Chinese players and identify issues for discussion at a higher level.

Establishing linkages at the provincial and local government levels to proactively identify and realize opportunities for investment and industrial cooperation.

Increasing talent development through educational exchanges to bridge the cultural divide.

\section{Boost trade and industrial integration through an FTA}

A potential FTA between China and the GCC could help reinforce economic and trade diversification for both sides. The elimination of import duties would lead to incremental annual sales of selected plastics products from Saudi Arabia to China, resulting in net welfare gains for China. Instead of creating trade conflicts and pursuing narrow, shortterm interests, integrated cooperation between Saudi Arabia and China along the petrochemical supply chain could help move the parties beyond a zero-sum game while reducing the risks of structural change.

An FTA could also accelerate the flow of foreign investment between both countries and extend the export of competitive industrial products to third markets, including the BRI network market and the Kingdom's MENA and European markets. Such an FTA could build on the complementary advantages of both countries and balance the factors of production for economic transition. 
4. Encourage a public-private partnership model for long-term financing

There are inherent challenges for infrastructure finance, including the requirement of long-term commitments of financial resources to an investment which is typically illiquid. Infrastructure finance also needs to counter long-term risks arising from geopolitical uncertainty and structural changes to labor and investment policies. A new financing model is needed to separate these two types of risk, currently shouldered by the banking and public sectors, and distribute them to a broader pool of investors. This new model may include a shift to a public-private partnership (PPP) model and a blended financing portfolio, including infrastructure bonds, infrastructure funds, and securitized or collateralized infrastructure loans, in addition to direct equity investments and bank loans.

Such a financing model would, unlike traditional engineering, procurement and construction contracting, require the establishment of PPP legal frameworks and a systematic design of the role that a broader group of investors could play in different stages of projects. Governments have a key role in setting up investable projects and creating a comprehensive data platform for infrastructure and industrial development. Such a platform could provide investors with the necessary project information and help them assess the opportunities at a low cost.

\section{Build a best practice platform for energy cooperation}

Energy is the core area of collaboration between China and Saudi Arabia. The emergence of new elements and new approaches comes at a time when both countries are undergoing economic and energy reforms. Even if the framework for energy collaboration is structured, both sides still need a platform upon which to research and catalyze cooperation. This platform might cover issues ranging from international energy governance to domestic energy reforms, with the aim of improving energy productivity and economic sustainability in both countries. Governments, research institutes and enterprises all have important roles to play in shaping the vision of the collaboration and facilitating its realization. Key elements of the platform could include:

Conducting joint research on global energy issues, such as energy security, energy market stability, green and low-carbon energy transformation.

Participating in and contributing to the research and development of government-level energy cooperation planning.

Creating opportunities for knowledge sharing on energy strategy, energy policy, and energy supply chain recreation.

Cooperating on energy reforms. Both sides could discuss and learn from each other regarding changes to their national energy governance, energy pricing systems, and managing the impact of energy reforms on industrial competitiveness and social welfare.

Facilitating the dissemination and collaboration of new energy technology. There is significant potential for joint research into and the development of new energy technologies. This platform could identify and disseminate the needs of both countries to encourage government-funded technology centers or businesses on which to collaborate. 
Al-Kibsi, Gassan, Jonathan Woetzel, Tom Isherwood, Jawad Khan, Jan Mischke, Hassan Noura. 2015. "Saudi Arabia Beyond Oil: The Investment and Productivity Transformation." McKinsey Global Institute, December.

Aloadah, Yasser, Guy Eikhoury, Fahim Bashir. 2016. "Upgrading the Saudi Chemical Cluster." Institute for Strategy and Competitiveness, Harvard University.

Saudi Aramco. 2016. "Agreements signed with Chinese companies." September 15. Accessed August 30, 2018. http://china.aramco.com/zh/home/news-and-media/news/ aramco_s-mous-with-china.html

Asharq AL-Awsat News. 2017. "Saudi Arabia and China sign MOUs." August 25.

Balazs, Horvath. 2016. "Identifying Development Dividends along the Belt and Road Initiative:

Complementarities and Synergies between the Belt and Road Initiative and the Sustainable Development Goals." UNDP and CCIEE Joint Report.

Bao, Chengzhang. 2018. "Status, Risk and Countermeasure for China to Advance the Construction of BRI in Saudi Arabia." Arab World Studies 4: 74-89.

Barton, Dominic, Li Guangyu, Lv Wenbo, Wang Weifeng. 2015. "One Belt and One Road-from Vision to Action." McKinsey China, May 27.

Boao Forum for Asia. 2018. Progress of Asian economic integration annual report 2018. Beijing: University of International Business and Economics Publishing House.

Capannelli, Giovanni, Jong-Wha Lee, and Peter Petri. 2009. "Developing Indicators for Regional Economic Integration and Cooperation." ADB Working Paper Series on Regional Economic Integration.

Chan, Craig and Wee Choon Teo. 2018. "RMB internationalization prospects and challenges." BRINK Asia. June 12.
Chen, Bo and Yuen Pau Woo. 2008. A Composite Index of Economic Integration in the Asia-Pacific Region. Simon Fraser University. Burnaby BC: Canada.

Chen, Dongmei, Guangyun Fu, Nicholas Howarth, Alessandro Lanza, Padu S. Padmanabhan, Kang Wu. 2018a. "Fostering Joint Leadership on Energy Productivity Transitions in Saudi Arabia and China." KAPSARC workshop brief, July. https://doi.org/10.30573/ ks--2018-wb18

Chen, Dongmei, Guangyun Fu, Nicholas Howarth, Alessandro Lanza, Padu S. Padmanabhan. 2018b. "Toward Economic Prosperity Through Industrial Energy Productivity Improvement." KAPSARC discussion paper, February. https://doi.org/10.30573/ks--2018-dp28

Chen, Xin and Chengyu Yang. 2016. "A quantitative analysis on China-CEEC economic and trade cooperation." Working Paper Series on European Studies, Institute of European Studies Chinese Academy of Social Sciences.

China Daily. 2017. "Pan-Asia's Saudi project to break ground next March." June 27.

China Development Bank, United Nations Development Program and Peking University (CDB, UNDP and PKU). 2017. "The Economic Development along the Belt and Road."

China Net. 2017. "Jazan China Industrial Park." April 25.

China Tourism Association (CTA) and Ctrip. 2018.

"China's Overseas Tourism Big Data 2017."

Dreher, Axel. 2006. "Does Globalization Affect Growth? Evidence from a New Index of Globalization." Applied Economics 38: 1091-1110. https://doi.org/10.1080/00036840500392078

Ehlers, Torsten. 2014. "Understanding the challenges for infrastructure finance." BIS working papers. 
Energy Information Administration (EIA). 2018. "China Surpassed the United States as the World's Largest Crude Oil Importer in 2017." https://www.eia.gov/ todayinenergy/detail.php?id=34812

Gong, Sihong. 2017. "Impact of Saudi Policy on Chinese Engineering and Construction Enterprises." Journal of International Economic Cooperation 11:87-90.

Gulf Petrochemical \& Chemical Association (GPCA). 2015. "The GCC Petrochemical and Chemical Industry: Facts and Figures 2017."

Gulf Petrochemical \& Chemical Association (GPCA). 2017. "The GCC Petrochemical and Chemical Industry: Facts and Figures 2017."

Hobbs, David. 2018. Interview during KAPSARC workshop in Beijing, July 23.

Industrial Clusters (IC). 2018. "Industrial Clusters." https://www.ic.gov.sa/en/clusters/

International Trade Centre (ITC). 2018. Trade Map.

Jadwa Investment. 2016. "Vision 2030: A New Trade and Investment Model in the Making." September.

Jadwa Investment. 2017. "Petrochemicals and the Vision 2030." February.

Johnson, Christopher K. 2016. "President Xi Jinping's 'Belt and Road Initiative."' CSIS report.

Liu, Dong. 2017. "Promoting China-Arab Capacity Cooperation through Building Overseas Industrial Parks." Journal of West Asia and Africa 6: 114-136.

Ma, Chaoxu. 2018. Speech at the high-level workshop for BRI and 2030 Sustainable Development Agenda. http://www.china-un.org/chn/hyyfy/t1568734.htm
Manyika, James, Jonathan Woetzel, Richard Dobbs, Jaana Remes, Eric Labaye, and Andrew Jordan. 2015 "Can Long-Term Global Growth Be Saved?" McKinsey Global Institute. January.

Ministry of Labor and Social Development (MLSD). 2016. Saudi Arabia Labor Market Report 2016. Saudi Ministry of Labor and Social Development.

Ministry of Commerce of the People's Republic of China (MOFCOM). 2017. "Outward Investment Guideline (Saudi Arabia)." Chinese government. https://www.yidaiyilu.gov. cn/zchj/zcfg/6829.htm

Mukherji, Indra Nath and Kavita lyengar. 2013. "Deepening Economic Cooperation between India and Sri Lanka." Mandaluyong City, Philippines: Asian Development Bank.

Overholt, William H. 2017. "Challenges Put Brakes on Yuan Internationalization.” January 11. Nikkei Asian Review.

Rakhmat, Muhammad Zulfikar. 2014. "China and Saudi Arabia: Strengthening ties through education." Daily Sabah-Opinion. April 13.

Rashad, Marwa. 2014. "Saudi central bank: China yuan good diversifier, but far from reserve currency." Reuters, March 16.

Royal Commission for Jubail and Yanbu (RCJY). 2017. "Jazan City for Primary and Downstream Industries." Quarter Report Q3.

Saudi Industrial Development Fund (SIDF). 2018. "Industrial Development in Saudi Arabia." Government Update, August 2.

Sinopec. 2018. "Oil Demand Pathways in China: Outlook and Sectoral Drivers." Presentation to KAPSARC workshop in Beijing, "China's Policy Drivers of Future Energy Demand." July 23-24. DOI: https://doi. org/10.30573/ks--2018-wb21 
Small, Andrew. 2015. The China-Pakistan Axis: Asia's New Geopolitics. London: Hurst \& Company, 103-105.

United Nations Conference on Trade and Development (UNCTAD). 2018. World Investment Report 2018. New York and Geneva: United Nations.

World Tourism Organization (UNWTO). 2017. "Penetrating the Chinese Outbound Tourism Market - Successful Practices and Solutions." World Tourism Organization.

Wang, Nengquan. 2018. "China's Oil Imports: Economic, Regulatory and Policy Drivers." Presentation to KAPSARC workshop in Beijing, "China's Policy Drivers of Future Energy Demand." July 23-24. https://doi. org/10.30573/ks--2018-wb21
World Travel \& Tourism Council (WTTC.) 2018. "Travel \& Tourism - Economic Impact 2018 Saudi Arabia." https://www.wttc.org/-/media/files/reports/economicimpact-research/countries-2018/saudiarabia2018.pdf

Xinhua Net. 2018. "Chinese enterprises organized a job fair in Riyadh for Saudi students who studied in China." September 6. http://www.xinhuanet.com/politics/201809/06/c_1123391360.htm

Zhang, Liang, Qiaohong Yang, and Qinglin Duan. 2016. Economic and Trade Development between China and Arab States 2016. Beijing: Social Sciences Academic Press. 


\section{About the Authors}

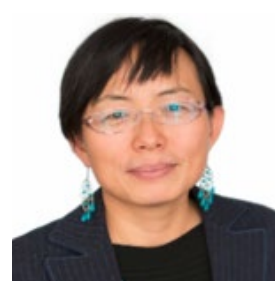

\section{Dongmei Chen}

Dongmei is a research fellow in the Market \& Industrial Development Program at KAPSARC. She has more than 20 years' experience working in the energy and climate field in China. Before joining KAPSARC, Dongmei was the head of the Institute of Industrial Productivity China Office and Director of Climate Change and Energy Program for WWF China.

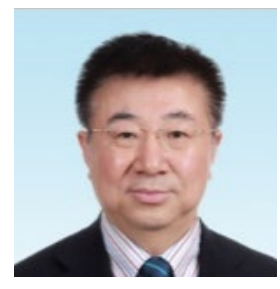

\section{Wenke Han}

Professor Han is a senior research fellow at the Energy Research Institute (ERI) of National Development and Reform Commission of China. He has worked for ERI since 1982 and acted as Director General of ERI from 20062016. His research focuses on China's national energy development strategies and plans, national energy security, sustainable energy policies, energy market reform, energy subsidies reform and global energy governance.

\section{About the Project}

First raised by Chinese President Xi Jinping in 2013 and officially launched by the Chinese government in March 2015 as The Vision and Actions on Jointly Building Silk Road Economic Belt and 21st Century Maritime Silk Road, China's evolving Belt and Road Initiative (BRI) has been a subject of great interest when analyzing the impact of Chinese policies on the international community.

This project focuses on assessing the overall progress of bilateral collaboration, analyzing the changing role of energy-focused outward direct investment and mapping the potential of the energy service market, with the aim of helping integration between China's BRI and Saudi Vision 2030. 
Notes

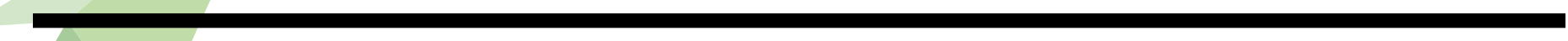


INAPSARC

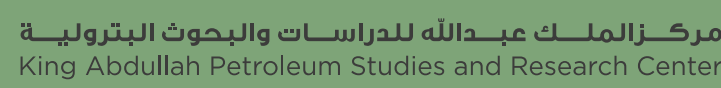

www.kapsarc.org 